\title{
Gender differences in violent outcome and risk assessment in adolescent offenders after residential treatment
}

Citation for published version (APA):

Lodewijks, H., de Ruiter, C., \& Doreleijers, T. (2008). Gender differences in violent outcome and risk assessment in adolescent offenders after residential treatment. International Journal of Forensic Mental Health, 7(2), 133-146. https://doi.org/10.1080/14999013.2008.9914410

Document status and date:

Published: 01/01/2008

DOI:

10.1080/14999013.2008.9914410

Document Version:

Publisher's PDF, also known as Version of record

\section{Document license:}

Taverne

Please check the document version of this publication:

- A submitted manuscript is the version of the article upon submission and before peer-review. There can be important differences between the submitted version and the official published version of record.

People interested in the research are advised to contact the author for the final version of the publication, or visit the DOI to the publisher's website.

- The final author version and the galley proof are versions of the publication after peer review.

- The final published version features the final layout of the paper including the volume, issue and page numbers.

Link to publication

\footnotetext{
General rights rights.

- You may freely distribute the URL identifying the publication in the public portal. please follow below link for the End User Agreement:

www.umlib.nl/taverne-license

Take down policy

If you believe that this document breaches copyright please contact us at:

repository@maastrichtuniversity.nl

providing details and we will investigate your claim.
}

Copyright and moral rights for the publications made accessible in the public portal are retained by the authors and/or other copyright owners and it is a condition of accessing publications that users recognise and abide by the legal requirements associated with these

- Users may download and print one copy of any publication from the public portal for the purpose of private study or research.

- You may not further distribute the material or use it for any profit-making activity or commercial gain

If the publication is distributed under the terms of Article $25 \mathrm{fa}$ of the Dutch Copyright Act, indicated by the "Taverne" license above, 


\title{
Gender Differences in Violent Outcome and Risk Assessment in Adolescent Offenders After Residential Treatment
}

\author{
Henny P. B. Lodewijks , Corine de Ruiter \& Theo A. H. Doreleijers
}

To cite this article: Henny P. B. Lodewijks, Corine de Ruiter \& Theo A. H. Doreleijers (2008) Gender Differences in Violent Outcome and Risk Assessment in Adolescent Offenders After Residential Treatment, International Journal of Forensic Mental Health, 7:2, 133-146, DOI: 10.1080/14999013.2008.9914410

To link to this article: https://doi.org/10.1080/14999013.2008.9914410

\section{Published online: 17 May 2010.}

Submit your article to this journal $\sqsubset$

山 Article views: 302

View related articles $₫$

Citing articles: 2 View citing articles 


\title{
Gender Differences in Violent O utcome and Risk Assessment in Adolescent 0 ffenders After Residential Treatment
}

\author{
Henny P. B. Lodewijks, Corine de Ruiter, and Theo A. H. Doreleijers
}

In light of the increase of violence in female adolescents during the past few decades, not only preventive, but also remedial strategies are important to mitigate this trend. Once high-risk female adolescents enter the juvenile justice system, it is important to be able to use reliable and valid instruments to predict reoffending. However, only a few studies have focused on risk assessment specifically addressing female adolescents. This prospective study examined gender differences in violent recidivism over an average follow-up period of 18 months after discharge, making use of the Dutch version of the Structured Assessment of Violence Risk in Youth (SAVRY). The SAVRY was coded for 35 female adolescents and a comparison sample of 47 male adolescents on the basis of file information before their release. The juvenile court had referred all these juveniles to a juvenile justice facility, because of violent offending and severe behavioral problems. Data on recidivism were retrieved from the Identification Service System of the National Police Services. Significant differences were found between the two gender groups on a number of SAVRY items. The predictive validity of the SAVRY for violent recidivism was good for girls $(A U C=.85)$ and for boys $(A U C=.82)$. However, false positives for girls were found more frequently than for boys. Implications for gender specific risk assessment and risk management in clinical practice are discussed.

Antisocial behavior among girls is becoming an increasing concern in society. In The Netherlands, the number of registered criminal acts committed between 1998 and 2003 by girls aged 12 to 18 years per 10,000 inhabitants increased from 110 to 163 $(+48 \%)$. By comparison, for boys this increase was from 719 to $821(+14 \%)$ in the same period (Eggen et al., 2005). In particular, a striking increase (300\%) of interpersonal violent acts committed by girls has been demonstrated from 1960 to 2003 . The girl-toboy ratio for charged violent crimes increased during the 20 years from 1980 to 1999 from 1:15 to $1: 5$ (Kruissink \& Essers, 2001). By comparison, in 2001 this ratio for charged violent crimes was $1: 2.5$ in the U.S. (FBI, 2001). Steffensmeier, Schwarz, Zhong, and Ackerman (2005) concluded after an examination of recent trends in girls' violence, that several policy shifts have apparently escalated girls' arrestproneness: first, stretching definitions of violence to include minor incidents that girls are more likely to commit; second, increased policing of violence between close friends and in private settings (for example, home, school) where girls' violence is more widespread; and, third, less tolerant family and societal attitudes toward juvenile female offenders.

Most studies on adolescent female aggression are based on normative, epidemiological studies (Odgers \& Moretti, 2002). The central conclusion in normative studies was that risk factors for antisocial behavior were remarkably similar for males and females (Fergusson \& Horwood, 2002; Moffitt, Caspi, Rutter, \& Silva, 2001). These findings from normative samples contrast with results from research with high risk juveniles in the justice system. Although high risk boys and girls demonstrate the presence of similar risk factors, such as maltreatment, low SES, and substance use, girls are more likely to exhibit concurrent and elevated levels of risk across multiple domains (Moretti, Holland, \& McKay, 2001). Garvazzi, Yarcheck, and Chesney-Lind

Henny P.B. Lodewijks, PhD, Rentray (Juvenile Correctional and Treatment Facility), Eefde, The Netherlands; Corine de Ruiter, $\mathrm{PhD}$, Department of Psychology, Maastricht University, Maastricht, The Netherlands; Theo A. H. Doreleijers M.D., PhD, VU University Medical Center Amsterdam, The Netherlands.

This study was financially supported by the Dutch Ministry of Justice and the Rentray Foundation. Special thanks go to Henny de Wit-Grouls, M.Sc. who participated as a research assistant in the study.

Address for correspondence: Henny Lodewijks, Box 94, 7200 AB Zutphen, The Netherlands (E-mail: hlodewijks@rentray.nl). 
(2006) found that girls in the juvenile justice system exhibit more problem behavior that may lead them into serious trouble. Girls had more problems than boys in family and peer relations, physical health, mental health and traumatic events. Findings from a study of a stratified sample of adjudicated juvenile delinquents indicated that females have significantly higher rates of psychopathology, maltreatment history, and more familial risk factors than males (McCabe, Lansing, Garland, \& Hough, 2002). Girls in juvenile justice samples are more likely to have experienced severe physical and sexual victimization (Chesney-Lind \& Sheldon, 1998; Hamerlynck, Doreleijers, Vermeiren, Jansen, \& Cohen-Kettenis, 2007). On the basis of a meta-analytic review, Edens and Campbell (2007) concluded that the weighted mean effect size of psychopathy, as measured by the Psychopathy Checklist: Youth Version (PCL: YV), for female offenders was appreciably lower than that for male samples. Psychopathy includes characteristics like: trying to manipulate others; callous or lacking empathy; not taking responsibility for actions; having friends who are in trouble with the law.

Although, in general, girls' offenses are less serious, some researchers have highlighted girls' involvement in assaults. In many instances, these assaults occur in the context of their relationships with others. For instance, a qualitative study of girls' assault records indicated that many of the assaults occurred between girls and their parents (Acoca, 1999). Some researchers have found that girls' involvement in more serious, violent crimes is due to their relationships with males who are criminal, or due to their affiliation with gangs (Acoca, 1999; Molidor, 1996).

Once female adolescents have entered the juvenile justice system it is important to have remedial interventions at one's disposal to prevent violent reoffending. Preferable, remedial interventions targeted at reducing the risk of violent recidivism in offenders are based on structured professional risk assessment (Borum, 1996). However, while the field of violence risk assessment among male adolescents has progressed rapidly over the past decade (Borum \& Verhaagen, 2006; Hoge, 2002; Lodewijks, Doreleijers, de Ruiter, 2008-a; Lodewijks, Doreleijers, de Ruiter \& Borum, 2008b; Schmidt, Hoge, \& Gomes, 2005), limited research is available on risk assessment with high risk female adolescents (Odgers, Moretti, \& Reppucci, 2005). Odgers et al. (2005) stated that predicting violence in girls faces different issues compared to violence in males or adult females, such as the low base rate of traditional forms of violence among females, the different expression of violence among females as compared to males, the significance of a violent history, and an early onset of antisocial and aggressive acts as a predictor of future violence. Violent female adolescents tend to disappear in statistical records when traditional violence measures are used and if they engage in violent behavior; as an adult, it often happens within the home and has less chance of being detected.

\section{This Study}

The use of violence risk assessment instruments can only be helpful if they are reliable and valid; that is, among a group of juvenile offenders the measure is sensitive to the factors that distinguish future reoffenders from non-reoffenders. This study was designed to examine possible gender differences in reliability and validity of a widely used risk assessment tool for violence, the SAVRY (Structured Assessment of Violence Risk in Youth; Borum, Bartel \& Forth, 2002). The SAVRY is a risk assessment tool based on the structured professional judgment model and intended for use with adolescents. The structure of the SAVRY is modeled on existing risk assessment instruments for adults such as the Historical, Clinical, Risk Management-20 (HCR-20; Webster, Douglas, Eaves, \& Hart, 1997), but its item content focuses on risk factors relevant to adolescents.

The SAVRY guideline is composed of 24 risk items, divided into three domains (historical, social/ contextual and individual) and a protective domain with six items. The risk items have a three-level coding structure (low, moderate, and high) and the protective items have a two-level structure (absent or present). Specific coding guidelines are provided for each item and each level. The SAVRY is a structured professional risk instrument. The SAVRY manual explicitly advises against the use of numerical indices and cut-off points in clinical decision making. The SAVRY Risk Total score is used only for research purposes. The Risk Total is 
derived by numerically transforming and summing codes of Low, Moderate and High for the 24 risk items, to 0,1 , and 2 , respectively. In clinical applications, the Summary Risk Rating is used. This rating is the qualitative final professional risk judgment, based on an overall interpretation of the 24 risk items and the six protective items for the case at hand. This Summary Rating is not directly linked to a particular Total score or range of scores.

Psychometric support for the SAVRY is presented in the manual (Borum et al., 2002) and on the website (www.fmhi.usf.edu/mhlp/savry/statement.htm). McEachran (2001) found relatively high reliability (.83) for the Risk Total score and a moderate coefficient (.72) for the Summary Risk Rating. Significant correlations have been found between Risk Total scores and measures of violence among young male offenders in Canada (Catchpole \& Gretton, 2003; Gretton \& Abramowitz, 2002). Using Receiver Operating Characteristic (ROC) analysis, Areas under the Curve (AUCs) for the Risk Total average between .74 and .80 across these studies. Interestingly, the examiner overall risk judgment (Summary Risk Rating) consistently performs as well as, and often better, than the actuarial combination of the scores. For example, using ROC analysis, McEachran (2001) found an AUC for the SAVRY Risk Total of .70, but the AUC for the SAVRY Summary Risk Rating was .89 .

To our knowledge, thus far, only one study has examined the SAVRY in female adolescents. Fitch (2002) followed 82 high-risk adolescent Native American youth (47 male, 35 female) after discharge. The correlations between SAVRY ratings and violent reoffense were significant for both gender groups, but higher for girls compared to boys on all scales.

On the basis of prior research, we hypothesize that:

(1) Violent recidivism will be associated with other risk and protective items in female adolescents, compared to male adolescents.

(2) Violent recidivism rates will be higher for boys than for girls.

(3) Violence in male adolescents will be more addressed towards strangers than violence in female adolescents.

(4) The static Historical domain will have less predictive power for violence than the dynamic
Social/Contextual, Individual and Protective domains, for both boys and girls.

(5) The SAVRY Summary Risk Rating and the SAVRY Risk Total will have good predictive validity for violent reoffending, for both girls and boys.

(6) The SAVRY Summary Risk Rating will add incremental value to the SAVRY Risk Total, for both girls and boys.

\section{METHOD}

\section{Setting}

The present study was conducted in Rentray, one of the thirteen juvenile justice facilities in The Netherlands. Rentray has a national coverage and is a treatment and correctional facility for 400 male and female juveniles between 12 and 22 years of age. Youths were placed in Rentray by the juvenile court because of serious offenses and/or serious behavioral problems. Treatment methods include individual cognitive therapy, group therapy, experiential art therapy, anxiety and aggression management, impulse control training, drug and alcohol treatment, social skills training, and family therapy. Rentray runs a number of semi-secure and secure units. The present study was conducted in the semi-secure treatment units.

\section{Procedure}

First, we selected from the Rentray records the girls with a violent offense in their history. For most of these girls the juvenile judge decided on a civil supervision order. They were subsequently sent to a closed juvenile justice facility before they entered the semi-secure facility of Rentray. Second, we formed a comparison group of boys. For both gender groups, the Dutch language version of the SAVRY (Lodewijks, Doreleijers, de Ruiter, \& de Wit-Grouls, 2003) was coded, making use of all file information available before discharge.

The two raters were Master's level psychologists, trained in coding the SAVRY during a two-day workshop given by a senior clinical psychologist (the first author). This workshop reviewed the relevant empirical literature and provided practice cases for 
coding the SAVRY using file information of actual cases. Raters were instructed to use the SAVRY manual and all available file information for all cases.

In order to establish the interrater reliability, each rater independently coded 14 cases $(40 \%)$ of the female sample and 14 cases $(30 \%)$ of the male sample. Subsequently, both raters discussed their ratings, and agreed upon a consensus rating and the final risk judgment. After the training and consensus meetings, each rater independently coded half of the remaining files. The 28 consensus SAVRY ratings and the 54 single-rated SAVRYs were used for subsequent analyses of predictive validity. The mean follow-up period for the girls was 546 days $(S D=$ 216 , range $=91-877)$, and for the boys 504 days $(S D$ $=200$, range $=93-877)$. The mean follow-up period for girls and boys did not differ significantly, $t(80)$ $=-90, p=.37$.

Table 1

Sample Characteristics

\section{Participants}

The current sample included 35 girls and 47 boys admitted to Rentray between August 2000 and April 2004. They were discharged between February 2003 and January 2005. Table 1 presents demographic, psychiatric and criminal history characteristics for the female and male samples. The samples are not comparable on type of sentencing. Despite the same index offense, girls were significantly more often sentenced with a civil supervision order and boys more often with a mandatory treatment order or a detention order. The general breakdown of violent offenders at the Rentray foundation is the same as found in this sample. Entrance ages ranged for the boys between 15 and 17 and for the girls between the ages of 14 and 17. The ages at the time of their leave ranged for boys between 16 and 19 and for

\begin{tabular}{lcc}
\hline & Girls & Boys \\
& $N=35$ & $N=47$ \\
\hline Demographic & & \\
Mean age upon admission & 15.6 & 15.7 \\
Mean age at discharge & 17.2 & 17.6 \\
Mean duration of stay in days & 614 & 685 \\
Caucasian Dutch & $23(66 \%)$ & $27(57 \%)$ \\
& & \\
Psychiatric & & $18(38 \%)$ \\
Conduct Disorder & $14(40 \%)$ & $23(49 \%)$ \\
Oppositional Defiant Disorder & $14(40 \%)$ & $25(53 \%)$ \\
Other Axis I disorders & $21(60 \%)$ & 89.9 \\
Mean intelligence scores & 93.6 & \\
& & $2(6 \%)$ \\
Violent index offenses & & $1(3 \%)$ \\
(Attempted) manslaughter & $3(6 \%)$ & $21(60 \%)$ \\
Sexual violence & $2(4 \%)$ & $11(31 \%)$ \\
(Aggravated) assault & $28(60 \%)$ & \\
Robbery & $14(30 \%)$ & $20(42 \%)^{*}$ \\
Court ordered interventions & & $21(45 \%)^{*}$ \\
Supervision order & $26(77 \%)$ & $6(13 \%)^{*}$ \\
Detention order & $7(20 \%)$ & \\
Mandatory treatment order & $1(3 \%)$ & \\
\hline
\end{tabular}

Note. Psychiatric disorders according to the DSM-IV (APA, 1994). * $p<.05$. 
girls between 15 and 19. The sample is representative of other violent offenders at Rentray. Of the total population of Rentray about $40 \%$ of the boys and $15 \%$ of the girls have violent offense histories.

\section{Violent Recidivism}

Violent recidivism data were retrieved from the Identification Service System, managed by the National Police Service. This system provides national coverage and has been used by the police since 1986 to register information on suspects. It contains information on reported crimes and personal information on the corresponding suspects. The information includes persons who are at least 12 years old and are named as suspects in a police report. An estimated $10 \%$ of the suspects are offered an outof-court settlement by the Public Prosecutor, or are found not guilty in the court at a later stage (Blom, Oudhof, Bijl, \& Bakker, 2005). For the identification of violent offenses we adopted the SAVRY definition of violence: "an act of battery or physical violence that is sufficiently severe to cause injury to another person or persons (i.e., cuts, bruises, broken bones, death, etc.) regardless of whether injury actually occurs; any act of sexual assault; or a threat made with a weapon in hand" (Borum et al., 2002, p. 29).

\section{Statistical Analyses}

Student's $t$-tests were used to examine the differences between the two gender groups and SAVRY variables. The interrater reliability was assessed by means of the Intraclass Correlation Coefficient (ICC), using the two-way random effects variance model and consistency type (McGraw \& Wong, 1996). We used the following critical values for single measure ICCs: ICC $\geq .75=$ excellent; .60 $\leq \mathrm{ICC}<.75=$ good; $.40 \leq \mathrm{ICC}<.60=$ moderate; ICC $<.40=$ poor (Fleiss, 1986).

Predictive validity was assessed by using Receiver Operating Characteristics (ROC) analysis (Mossman, 1994; Rice \& Harris, 1995). This statistical method is less reliant than other statistical analyses (like correlation coefficients) on the base rates of recidivism and the particular cut off score chosen to classify cases. Also normality need not be assumed. ROC analyses result in a plot of the true positive rate (sensitivity) against the false positive rate (1 minus specificity) for every possible cut-off score of the instrument. The resulting Area Under the Curve (AUC) can be interpreted as the probability that a randomly selected recidivist would score higher on the instrument than a randomly selected nonrecidivist. An AUC of .50 represents chance prediction, and an AUC of 1.0 perfect prediction. In general, AUC values of .70 and above are considered moderate, and above .75 good (Douglas, Guy, \& Weir, 2005).

Survival analysis, also referred to as the KaplanMeier method, was used to calculate recidivism rates and the average time prior to that event. Survival analysis calculates the probability of recidivating for each time period given that the offender has not yet reoffended. Once an offender recidivates, he is removed from the analysis for the subsequent time periods. Survival analysis has the advantage of being able to estimate year-by-year recidivism rates even when the follow-up period varies across offenders. The log rank statistic was used to test the differences between the survival curves of the subgroups. To evaluate effects of predictors on survival, the Cox proportional hazards model, which assumes that the hazard ratio is invariant across time (i.e., that the effect of a predictor variable is stable over time), was used (Hosmer \& Lemeshow, 1999). Violation of the assumption requires the time interaction effect and ensures that the estimation of the predictor is reliable.

\section{RESU LTS}

\section{Interrater Reliability}

The interrater reliability of the SAVRY subscales for girls ranged from good to excellent (ICC: Historical $=.92$, Social/Contextual $=.80$, Individual $=.72$, SAVRY Risk Total $=.82$, Protective $=.73$, and Summary Risk Rating $=.68$ ). The interrater reliability of the SAVRY subscales for boys also ranged from good to excellent (ICC: Historical $=$ .77 , Social/Contextual $=.94$, Individual $=.88$, SAVRY Risk Total $=.86$, Protective $=.83$, and Summary Risk rating $=.68$ ). In no case did one rater judge "high risk" while the other judged "low risk" on the Summary Risk Rating. 


\section{SAVRY O utcomes}

Table 2 presents the mean scores and standard deviations for the individual SAVRY items, subscales, Total Risk score and Summary Risk Rating, for girls and boys. As can be seen from this table, the mean SAVRY subscales, Total Risk scores and Summary Risk Ratings did not differ significantly between the female and male samples. However, there were significant differences on some individual SAVRY items. Girls received significantly lower scores on the items "Childhood history of maltreatment" and "Poor school achievement", and higher scores on "History of self-harm or suicide attempts". In the protective domain, item 4, indicating a more positive attitude towards interventions and authority, was significantly more present in girls. Regarding the Summary Risk Rating, girls were significantly more often judged as low and moderate risk, while boys were significantly more often judged as high risk. The mean Risk Total score per final risk judgment category for girls was: "low risk": 14 (range = 6-24); "moderate risk": 22.7 (range =17-27); "high risk": 30.1 (range=24-37). For boys, the mean SAVRY Risk Total score per final risk judgment category was: "low risk": 14.9 (range $=9$ - 21); "moderate risk": 20.1 (range = 14-27); "high risk": 25.1 (range = 18-34). The mean Risk Total scores differed significantly between the low, moderate and high risk cases for both boys and girls, $F(2,44)=24.4, p<.001$, and $F(2,32)=32, p<$ .001 , respectively. There were no significant differences between boys and girls in the mean Risk Total scores, when the final risk judgment was low, $t(28)=.51, p=.61$; or moderate, $t(25)=-1.9, p=$ .07 . We found a significant difference when the final risk judgment was high, $t(23)=-2.1, p=.01$, indicating that girls had a significantly higher Risk Total score when they were judged as high risk, compared to boys.

\section{Violent Recidivism}

Significantly more boys compared to girls reoffended violently: $17(36 \%)$ out of 47 boys vs. four $(11 \%)$ out of 35 girls, $\chi^{2}(1, N=21)=6.4, \mathrm{p}=$ .01 . When we accounted for time at risk and used survival analysis, this was 39\% for the boys and $13 \%$ for the girls. Figure 1 presents the survival curves for violent outcome. Survival analysis revealed that

Figure 1

Kaplan-Meier Survival Curves for Violent Recidivism in Male and Female Adolescents

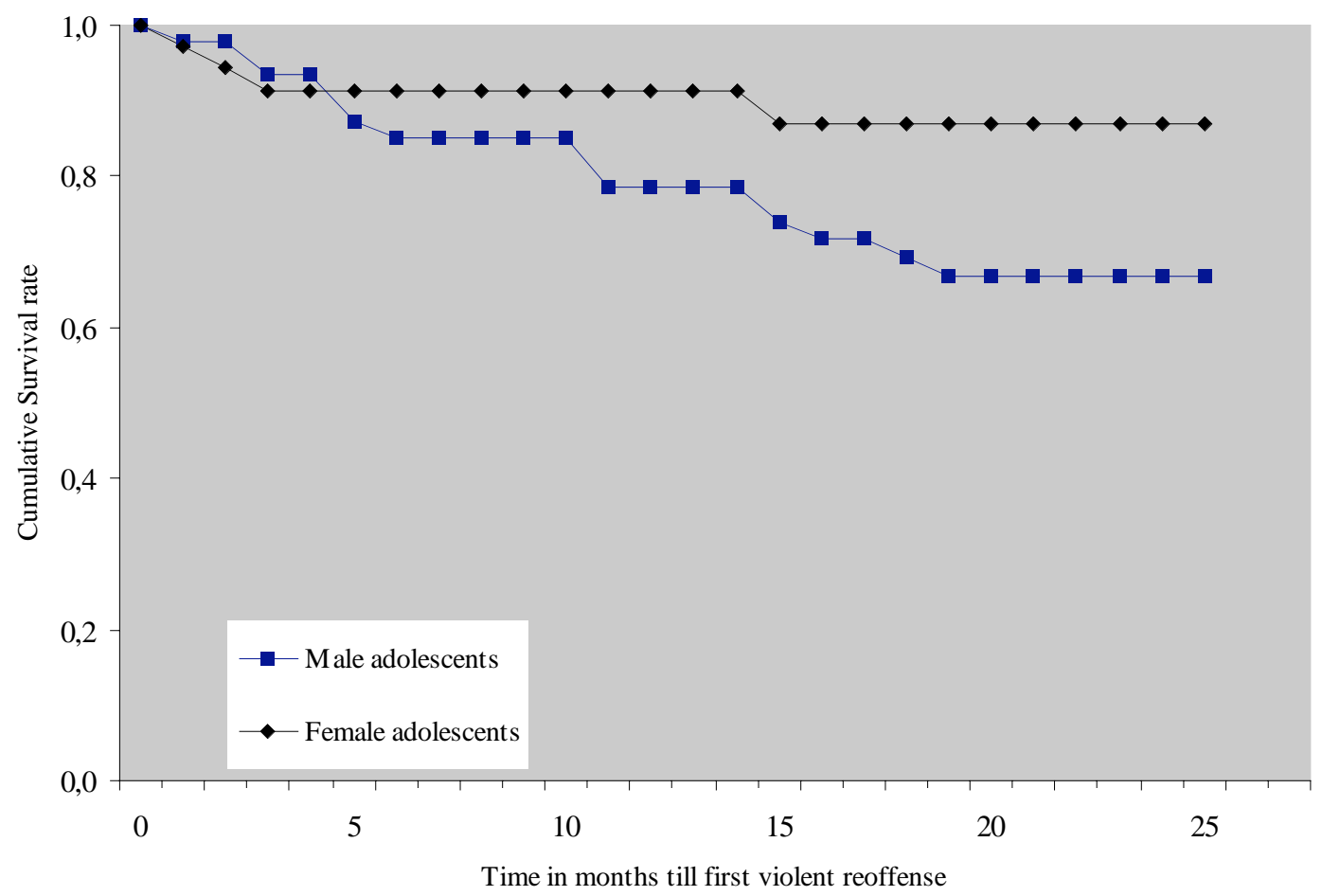


Table 2

Mean SAVRY Scores (Standard Deviations in Brackets) and Summary Risk Rating

\begin{tabular}{|c|c|c|}
\hline & $\begin{array}{c}\text { Girls } \\
N=35\end{array}$ & $\begin{array}{c}\text { Boys } \\
N=47\end{array}$ \\
\hline \multicolumn{3}{|l|}{ Historical items } \\
\hline 1. History of violence & $1.6(.49)$ & $1.7(.45)$ \\
\hline 2. History of nonviolent offending & $1.3(.73)$ & $1.6(.57)$ \\
\hline 3. Early initiation of violence & $0.7(.75)$ & $0.6(.74)$ \\
\hline 4. Past supervision/Intervention failures & $1.5(.66)$ & $1.2(.84)$ \\
\hline 5. History of self-harm or suicide attempts & $0.6(.74)$ & $0.3(.54)^{*}$ \\
\hline 6. Exposure to violence in the home & $0.5(.83)$ & $0.9(.97)^{*}$ \\
\hline 7. Childhood history of maltreatment & $0.9(.87)$ & $1.4(.81)^{*}$ \\
\hline 8. Parental/Caregiver criminality & $0.3(.67)$ & $0.6(.90)$ \\
\hline 9. Early caregiver disruption & $0.5(.82)$ & $0.8(.96)$ \\
\hline 10. Poor school achievement & $1.2(.72)$ & $1.8(.68)^{*}$ \\
\hline \multicolumn{3}{|l|}{ Social/contextual items } \\
\hline 11. Peer delinquency & $0.3(.62)$ & $0.4(64)$ \\
\hline 12. Peer rejection & $0.5(.70)$ & $0.6(.77)$ \\
\hline 13. Stress and poor coping & $0.9(.76)$ & $0.8(.83)$ \\
\hline 14. Poor parental management & $1.1(.76)$ & $1.3(.73)$ \\
\hline 15. Lack of personal/Social support & $0.7(.82)$ & $0.9(.87)$ \\
\hline 16. Community disorganization & $0.8(.98)$ & $0.7(.90)$ \\
\hline \multicolumn{3}{|l|}{ Individual items } \\
\hline 17. Negative attitudes & $0.7(78)$ & $0.8(.68)$ \\
\hline 18. Risk taking/Impulsivity & $0.6(.73)$ & $0.7(.78)$ \\
\hline 19. Substance use difficulties & $0.8(.72)$ & $0.7(.64)$ \\
\hline 20. Anger management problems & $0.9(.83)$ & $1.0(.66)$ \\
\hline 21. Low empathy/remorse & $0.6(.61)$ & $0.9(.78)^{*}$ \\
\hline 22. Attention Deficit/Hyperactivity Difficulties & $0.5(.74)$ & $0.6(.76)$ \\
\hline 23. Poor compliance & $0.5(.61)$ & $0.4(.62)$ \\
\hline 24. Low interest/Commitment to school or work & $0.5(61)$ & $0.4(.62)$ \\
\hline \multicolumn{3}{|l|}{ Protective items } \\
\hline 1. Prosocial involvement & $0.2(.38)$ & $0.1(.31)$ \\
\hline 2. Strong social support & $0.5(.50)$ & $0.3(.47)$ \\
\hline 3. Strong attachments and bonds & $0.3(.47)$ & $0.3(.44)$ \\
\hline 4. Positive attitude towards interventions and authority & $0.4(.50)$ & $0.2(.38)^{*}$ \\
\hline 5. Strong commitment to school or work & $0.5(.50)$ & $0.4(.50)$ \\
\hline 6. Resilient personality & $0.1(.35)$ & $0.1(.31)$ \\
\hline Historical domain & $9.3(3.7)$ & $10.7(3.0)$ \\
\hline Social/contextual domain & $4.3(2.7)$ & $4.8(2.4)$ \\
\hline Individual domain & $5.4(3.0)$ & $5.8(2.6)$ \\
\hline Risk Total score & $19(7.8)$ & $21(5.3)$ \\
\hline Protective domain & $1.8(1.5)$ & $1.4(1.4)$ \\
\hline Summary Risk Rating & $N(\%)$ & $N(\%)$ \\
\hline Low & $20(57 \%)$ & $10(21 \%)^{*}$ \\
\hline Moderate & $7(20 \%)$ & $20(43 \%)^{*}$ \\
\hline High & $8(23 \%)$ & $17(36 \%)^{*}$ \\
\hline
\end{tabular}

Note. ${ }^{*} p<.05$ (two-tailed). 
the survival functions in months for girls $(M=25.5)$ compared to boys $(M=20.1)$ differed significantly $(\log \operatorname{rank}=6.4, \mathrm{p}=.01)$.

Regarding type of violent reoffense, males committed more serious violence compared to girls (manslaughter: 2 vs. 0; rape: 1 vs. 0; aggravated assault: 1 vs. 1 ; simple assault: 7 vs. 3 ; robbery: 3 vs. 0 ). We did an analysis on age and did not find significant outcome differences on violent reoffending between age groups.

We also examined the relationship between the offender and the victim. With regard to the index offense, we found that boys, significantly more often than girls, had a stranger as a victim ( $55 \%$ vs. $26 \%)$, $\chi^{2}(1, N=82)=7.2, p=.002$. Regarding the reoffense, the difference was also significant (82\% vs. $25 \%), \chi^{2}(1, N=21)=5.2, p=.02$.

Although not part of our hypotheses, we also calculated the recidivism rate for general offending, and found a $40 \%$ rate for girls and $41 \%$ for boys.

\section{Predictive Validity}

Table 3 shows the AUC values of the Risk Total and Summary Risk Rating for both girls and boys regarding violent outcome. It was only the Historical scale, for girls and boys that did not yield a significant AUC value. All other AUC values of the SAVRY scales, the Risk Total and Summary Risk Rating were significantly above .50. For the Protective scale, the AUC was significantly below .50, because of the inversed relation between this scale and violent outcome: the more protective factors, the less violence. The difference in violent outcome between girls who were judged to pose a low, moderate or high risk was significant, $\chi^{2}(2, \mathrm{~N}=32)=6.5, \mathrm{p}=$ .04 (violent outcome: $0 \%, 22 \%$ and $33 \%$, respectively). The difference in outcome between boys who were judged to pose a low, moderate or high risk was also significant, $\chi^{2}(2,45)=15.7, p<.001$ (violent outcome: $0 \%, 22 \%$ and $68 \%$, respectively).

Although not part of our main analysis, we also calculated the AUC values for general recidivism and found no significant AUCs for girls on any of the subscales or Risk Total. For boys we found a significant association between the Individual scale $(\mathrm{AUC}=.68, \mathrm{p}<.05)$, the Protective scale $(\mathrm{AUC}=.74$, $p<.01)$ and for the Risk Total $(\mathrm{AUC}=.67, p<.05)$.
Next, as summarized in Table 4, we conducted Cox Regression analyses to determine whether the Summary Risk Ratings produced incremental value in the amount of variance explained by the Risk Total. For violent reoffending, the Risk Total score entered in Block 1 produced a significant model fit for girls and for boys. The addition of the Summary Risk Rating in Block 2 added an incremental value to the amount of variance explained. This finding only applied to boys, $\chi^{2}$ Change $(1,47)=5.3, p<.05$, and not to girls, $\chi^{2}$ Change $(1,35)=.01, n s$.

\section{DISCUSSION}

In this study, a sample of 35 violent girls was compared to a sample of 47 violent boys on SAVRY scores, violent recidivism, and the predictive validity of the SAVRY. We found several significant differences between girls and boys in sample characteristics, mean SAVRY individual item scores, and base rate for violence after discharge. The predictive validity of the SAVRY proved to be good for both girls and boys. The interrater reliability of the SAVRY in the present study ranged from good to excellent and was in line with previous studies with the Dutch version of the SAVRY (Lodewijks et al., 2008-a; Lodewijks et al., 2008-b). We found no differences in interrater reliability between girls and boys.

First, we found a number of differences in sample characteristics. Boys more often, albeit not significantly, had a diagnosis of disruptive behavior disorder compared to girls ( $87 \%$ vs. $80 \%$ ) and fewer other Axis I disorders (53\% vs. 60\%). This prevalence rate for disruptive disorders in boys is higher than the reported rate of $75 \%$ in an earlier study of Vreugdenhil, Doreleijers, Vermeiren, Wouters, and van den Brink (2004). However, in our sample only violent offenders were included compared to all types of offenders in the study of Vreugdenhil et al. (2004). The prevalence rate found in our sample of conduct disorder (40\%) in girls is lower than the prevalence rate of conduct disorder $(56 \%, N=216)$ in a representative sample of girls in juvenile facilities (Hamerlynck, Doreleijers, Vermeiren, Jansen, \& Cohen-Kettenis, 2007). However, Hamerlynck et al. based this finding on 
Table 3

Predictive Validity of the SAVRY for Girls and Boys

\begin{tabular}{|c|c|c|c|c|}
\hline & \multicolumn{2}{|c|}{$\begin{array}{l}\text { Violent recidivism girls } \\
\qquad N=35\end{array}$} & \multicolumn{2}{|c|}{$\begin{array}{l}\text { Violent recidivism boys } \\
\qquad N=47\end{array}$} \\
\hline & AUC & $\mathrm{SE}$ & AUC & $\mathrm{SE}$ \\
\hline \multicolumn{5}{|l|}{ SAVRY } \\
\hline Historical domain & .69 & .12 & .65 & .08 \\
\hline Social/contextual domain & $.88 *$ & .07 & $.73 * *$ & .07 \\
\hline Individual domain & $.87 *$ & .06 & $.78 * *$ & .07 \\
\hline Total Risk score & $.84^{*}$ & .09 & $.76^{* *}$ & .07 \\
\hline Protective domain & $.15^{*}$ & .07 & $.16^{* * *}$ & .06 \\
\hline Summary Risk Rating & $.85^{*}$ & .07 & $.82 * * *$ & .06 \\
\hline
\end{tabular}

Note. ${ }^{*} p<.05, * * p<.01, * * * p<.001$ (two-tailed). AUC = Area Under the Curve. $\mathrm{SE}=$ Standard Error.

Table 4

Cox Regression Analyses using Risk Total Scale and Summary Risk Rating to Predict Violent Reoffending

\begin{tabular}{|c|c|c|c|c|c|}
\hline & Covariates entered & $\chi^{2}$ & $p$ & $\chi^{2}$ Change & $p$ \\
\hline \multicolumn{6}{|l|}{ Male adolescents } \\
\hline \multirow{3}{*}{$\begin{array}{l}N=47 \\
\text { Failure rate }=36 \%\end{array}$} & Block 1: Risk Total scale & $8.1 * *$ & .004 & $8.4 * *$ & .004 \\
\hline & Block 2: & & & & \\
\hline & Summary Risk Rating & $16.9 * * *$ & $<.001$ & $11.3 * *$ & .001 \\
\hline \multirow{4}{*}{$\begin{array}{l}\text { Female adolescents } \\
N=35 \\
\text { Failure rate }=11 \%\end{array}$} & & & & & \\
\hline & Block 1: Risk Total scale & $5.3^{*}$ & .02 & $5.3^{*}$ & .02 \\
\hline & Block 2: & & & & \\
\hline & Summary Risk rating & 5.3 & .07 & .01 & .90 \\
\hline
\end{tabular}

Note. $\chi=$ Chi square. $* p<.05, * * p<.01, * * * p<.001$ (two-tailed). 
semi-structured interviews with the girls; whereas in the current study, the classification was derived from classifications by mental health experts using collateral information.

Of interest is our finding that the juvenile judge dealt significantly more often with violent girls by issuing a civil supervision order than with violent boys. Boys were significantly more often sentenced to a criminal justice order than girls with comparable index offenses. This finding is in line with the conclusion of Pajer (1998), who has described a gender bias in the justice system, i.e., the reluctance to arrest women coupled with a tendency toward psychiatric referrals for women. Thus, an underestimation of violence among girls would be the result if only the type of sentence was taken as the basic factor.

Second, there were no significant differences in mean SAVRY subscale scores and Risk Total scores for female or male adolescents. This finding differs from that of Fitch (2002), who found higher scores for boys. An explanation might be that in our sample the index offenses were comparable, whereas in the study of Fitch, boys committed more serious offenses than girls. Our finding that girls compared to boys, significantly differed in some SAVRY items is not always in line with previous research. The higher history of self harm or suicide attempts (item 5), and the better school achievement (item 10) are common findings in studies on gender differences (Penney \& Moretti, 2007). Contrary to expectation (Odgers, Moretti, et al., 2005) though, were the significantly higher scores for boys on item 7 "Exposure to violence in the home" and item 8 "Childhood history of maltreatment". The significantly lower prevalence of lack of empathy/remorse among female adolescents is in line with previous research into this concept (Odgers, Reppucci, \& Moretti, 2005). Finally, the higher presence for girls of the protective item 4, "Positive attitude towards interventions and authority", is in line with previous research found in adult female offenders (de Vogel \& de Ruiter, 2005).

Third, regarding violent outcome after discharge, male adolescents in our sample were found to be three times more likely to commit a violent reoffense than female adolescents (males: 36\%; females: 11\%). Unfortunately, a direct comparison with other followup studies in The Netherlands can not be made because specific information on violent recidivism is lacking. We only know that serious and very serious recidivism amounts to $35.5 \%$ for boys and $15.8 \%$ for girls two years after discharge (Wartna, Kalidien, Tollenaar, \& Evers, 2006). In this study serious and very serious crimes, in addition to violent crimes, also include serious drug crimes and burglary. Furthermore, unknown in these figures is whether the index offense was a violent crime, as in our sample. International comparison is difficult as well, because, as far as we know, most studies on recidivism after residential treatment do not specify a violent index offense followed by a violent reoffense. For instance, Schmidt et al. (2003) reported a recidivism rate of serious reoffenses in juveniles (male: $37.9 \%$, female: 15.9\%), including violent offenses, burglary, theft, arson and drug trafficking and of these subjects, $46 \%$ of the males and $26 \%$ of the females had a previous violent offense. Only Catchpole and Gretton (2003) reported a specific recidivism rate (index and reoffense are both violent offenses) of $23 \%$ in a male adolescent sample, one year after discharge. Our recidivism rate of $36 \%$ after 18 months is comparable to that of this study.

A possible explanation for the difference in violent recidivism between male and female adolescents in the community is that violence committed by females is often less visible, as in relational violence, child abuse, and violence against relatives (Robbins, Monahan, \& Silver, 2003). As hypothesized, we found a significant difference between girls and boys as to whether the victim was a stranger. For the index offense and for the reoffense, we found that boys' violence compared to girls' violence was more often directed towards a stranger. This finding could be explained by the fact that in general, females have different motives for their violent offenses compared to males, more often reactive and relational, and less instrumental or resulting from criminogenic needs (Crick \& Grotpeter, 1995).

Fourth, as hypothesized, we found poor predictive validity for the Historical scale, both for girls and boys. Contrary to our hypothesis, we found moderate predictive validity for the Social/ Contextual scale for boys. The poor predictive accuracy of the Historical scale was also found in a study on institutional violence (Lodewijks et al., 2008b), but not in the study of Fitch (2002). The 
possible poor predicting value of the Historical scale is very interesting, because this result suggests that violence prediction for juveniles, based solely on historical data is quite disputable. Hypothetically, the poor predictive power of the Historical scale might also be explained by the influence of treatment, which is represented in the dynamic scales. More research on this topic is needed.

All the other scales, except the Social/Contextual scale for girls which was good, yielded excellent predictive validity. Notable was the excellent predictive validity of the SAVRY final risk judgment for girls $(\mathrm{AUC}=.85)$ and boys $(\mathrm{AUC}=.82)$. In our sample, the final risk judgment did not outperform the simple addition of individual SAVRY risk factors, as was hypothesized on the basis of previous research (McEachran, 2001). However, the latter was a retrospective file study, where 108 young male offenders were evaluated at a youth forensic service. The outcome criterion used was official crimes committed after reaching adulthood, generally around a three-year follow-up period. By comparison, our study had a prospective design and we followed the juveniles for half this period. Because one does not know in advance who will recidivate and at what time, in risk assessment research a prospective design is preferable. Moreover, in a prospective design all data are available at the time of risk assessment. In a retrospective design it is more difficult to gather retrospectively all the necessary information. On the other hand, prospective designs will be hampered by the clinical goal of risk assessment, i.e. risk management and prevention (Hart, 1998). Thus, when clinicians perform SAVRY risk assessments it is likely that outcome influences decisions on leave and treatment plan, and at the end will influence also violent outcome. However, in our study SAVRY outcome was unknown to the clinicians and did not influence their decisions.

Fitch (2002) reported correlations and not AUCs between the SAVRY subscales and violent outcome in her study. She found significant correlations, for girls and for boys, and mostly higher correlations for girls compared to boys (Historical scale: .66 vs. .45; Social/Contextual scale: .74 vs. .47; Individual scale: .64 vs. .35; SAVRY Risk Total: .72 vs. .50). In a post hoc analysis, we found lower correlations for girls compared to Fitch's sample; they were significant for both sexes, except for the Historical scale (Historical scale: .27 vs. .24; Social/Contextual scale: .35 vs. .47; Individual scale: .46 vs. .40; SAVRY Risk Total: .46 vs. .43).

Finally, a few concluding remarks on gender differences in the use of SAVRY should be made. We found that girls had a significantly higher Risk Total score compared to boys when they were judged in the Summary Risk Rating as high risk. A possible explanation for this finding is that the raters in their training were taught that girls in general have a lower risk of violent reoffending. This could have affected their Summary Risk Rating. We found significant predictive validity of the SAVRY Summary Risk Rating. On closer look we found that the ratio of false negatives in the case of low risk was the same for girls and boys ( $0 \%$ vs. $0 \%)$, but the ratio of false positives in the case of high risk was higher, albeit not significantly so, for girls compared to boys $(66 \%$ vs. $32 \%), \chi^{2}(1,25)=2.3, p=.13$. It appears that the SAVRY final risk judgment has perfect predictive accuracy for low risk judgments in both males and females, and reasonable predictive accuracy for high risk judgments in male adolescents, but doubtful predictive accuracy for female adolescents. Furthermore, we hypothesized that the final risk judgment (Summary Risk Rating) would add incremental value to the Risk Total score. We found this to be true for boys but not for girls. These results indicate a more reluctant attitude towards risk assessment with female adolescents.

A number of limitations to the present study should be mentioned. First, the violent outcome data may have been an underestimation of actual violence. The violent recidivism data were retrieved from only one source, the Identification Service System, managed by the National Police Service. The persons in this system are suspected of a crime. The disadvantage of this system is that ultimately $10 \%$ will not be prosecuted because of lack of legal evidence and/or not being guilty. However, the advantage of the police registration system is that all suspects of violence are registered, which is especially important for girls, because they will disappear in statistical records when we make use of another source, in which only adjudicated crimes are included. As a consequence of using official registers, the reconviction rate in our study is inevitably an underestimation of the actual recidivism rate because not all offenders are reported. And 
this might explain the relative high ratio of false positives in girls, because they are underestimated in official records. Second, the sample sizes were relatively small and only derived from one site. However, given that there is such a paucity of research on adolescent females in juvenile justice facilities, we believe even samples of limited size, such as ours, can make a contribution to the knowledge base.

Based on this study, we have two suggestions for policy implications. Firstly, more attention should be paid in treatment programs to violent careers of violent girls, especially because of the danger of intergenerational transference when these girls have children of their own. Secondly, in preventive programs for violent offending in girls, more attention should be paid to relational violence.

More knowledge on specific risk factors for violence and the risk management strategies needed to prevent repeated violence in female adolescents are desirable. This is also important from a public mental health perspective because research has demonstrated an intergenerational transfer of risk of aggression between mothers and their children; mothers with a history of violent offense(s) more often have disruptive, aggressive children (Serbin et al., 1998). As on the SAVRY, other risk markers might be added in the item list to improve the prediction of violent outcome in female adolescents. Possible candidates for gender refinement not in the SAVRY, are: sexual abuse from the age of 12 (Chesney-Lind \& Sheldon, 1998; Corrado, Odgers, \& Cohen, 2001; McKnight \& Loper, 2002); psychiatric comorbidity (Das, de Ruiter, Lodewijks, \& Doreleijers, in press; Teplin, Abram, McClelland, Dulcan, \& Mericle, 2002; Hamerlynck et al., 2007); being lured into exploitative relationships, because of intense need for acceptance (Artz, 1998; Downey, 2002) and insecure attachment (Allen et al., 2002; Moretti, DaSilva, \& Holland, 2004). Religiosity was found to be a quite specific protective factor for girls and not for boys (Resnick, Ireland, \& Borowsky, 2004).

Our findings demonstrate that the method of structured professional judgment, i.e. systematically rating risk factors, integrating and weighing information, is effective in the prediction of violence for both female and male adolescents. For treatment purposes, we recommend that clinicians be cautious about the use of risk assessment in female adolescents. The higher probability of false positives in girls might cause prolonged incarceration or stricter probation conditions than necessary and this might cause demotivation and a counter-productive outcome.

\section{REFEREN CES}

Acoca, L. (1999). Investing in girls: A 21st century strategy. Juvenile Justice, 6, 3-13.

Allen, J. P., Marsh, P., McFarland, C., Boykin, K., Land, D., Jodl, K. M. et al. (2002). Attachment and autonomy as predictors of the development of social skills and delinquency during mid-adolescence. Journal of Consulting and Clinical psychology, 70, 55-66.

American Psychiatric Association (1994). Diagnostic and statistical manual of mental disorders - Fourth edition (DSM-IV). Washington, DC: American Psychiatric Association.

Artz, S. (1998). Where have all the school girls gone? Violent girls in the school yard. Child and Youth Care Forum, 27, 77-109.

Blom, M., Oudhof, J., Bijl, R. V., \& Bakker, B. F. M. (2005). Verdacht van criminaliteit. Allochtonen en autochtonen nader bekeken [Suspected of crime: A closer look at persons of foreign and Dutch heritage]. The Hague, The Netherlands: WODC/CBS.

Borum, R. (1996). Improving the clinical practice of violence risk assessment: Technology, guidelines and training. American Psychologist, 51, 945-956.

Borum, R., Bartel, P., \& Forth, A. (2002). Manual for the Structured Assessment of Violence Risk in Youth (SAVRY): Consultation edition (version 1). Tampa: University of South Florida.

Borum, R., \& Verhaagen, D. (2006). Assessing and managing violent risk in juveniles. New York: The Guilford Press.

Catchpole, R., \& Gretton, H. (2003). The predictive validity of risk assessment with violent young offenders: A 1-year examination of criminal outcome. Criminal Justice and Behavior, 30, 688-708.

Chesney-Lind, M., \& Sheldon, R. (1998). Girls, delinquency, and juvenile justice (2nd ed.). Pacific Grove, CA: Brooks/ Cole.

Corrado, R., Odgers, C., \& Cohen, I. (2001). The use of incarceration for female youth; Protection for whom? Canadian Journal of Criminology, 42, 189-206.

Crick, N. R., \& Grotpeter, J. K. (1995). Relational aggression, gender, and social-psychological adjustment. Child Development, 66, 710-722.

Das, J., Ruiter, C. de, Lodewijks, H. P. B., \& Doreleijers, Th. A. H. (2007). Predictive validity of the Dutch PCL:YV for institutional disruptive behavior: Findings from two samples of male adolescents in a juvenile justice treatment institution. Behavioral Sciences and the Law, 25, 739-755

Douglas, K. S., Guy, L. S., \& Weir, J. (2005). HCR-20 violence risk assessment scheme: Overview and annotated 
bibliography. Retrieved October 5, 2007, from http:// www.sfu.ca/psycholgy/faculty/hart/violink.htm

Downey, G. (2002, May). Predictors of consequences of rejection sensitivity in young women. Paper presented at the Vancouver Conference on Aggressive and Violent Girls: Contributing factors and Intervention Strategies, Vancouver, Canada.

Edens, J. F., \& Campbell, J. S. (2007). Youth psychopathy and criminal recidivism: A meta-analysis of the Psychopathy Checklist measures. Law and Human Behavior, 31, 53-75.

Eggen, A. Th. J., Laan, A. M. van der, Engelhard, B. J. M., Blom, M., Broeders, A. P. A., \& Bogaerts, S. (2005). Criminaliteit en opsporing [Criminality and detection]. In A. Th. J. Eggen \& W. van der Heide (Eds.), Criminaliteit en rechtshandhaving 2004: ontwikkelingen en samenhangen (pp. $89-$ 128). [Criminality and maintaining the law, 2004: Trends and associations]. The Hague, The Netherlands: WODC.

Fergusson, D. M., \& Horwood, J. H. (2002). Male and female offending trajectories. Development and Psychopathology, 14, 159-177.

Fitch, D. (2002). Risk assessment on 82 high-risk Native American youth. Unpublished doctoral dissertation. University of Texas-Clear Lake. Retrieved October 5, 2007, from http://www.fmhi.usf.edu/mhlp/savry/SAVRY_Research.htm

Fleiss, J. L. (1986). The design and analysis of clinical experiments. New York: Wiley.

Gavazzi, S. M., Yarcheck, C. M., \& Chesney-Lind, M. (2006). Global risk indicators and the role of gender in a juvenile detention sample. Criminal Justice and Behavior, 33, 597612.

Gretton, H., \& Abramowitz, C. (2002). SAVRY: Contribution of items and scales to clinical risk judgments and criminal outcomes. Paper presented at the American Psychology and Law Society, Biennial Conference, Austin, Texas. Retrieved October 5, 2007, from http://www.fmhi.usf.edu/mhlp/ savry/SAVRY_Research.htm

Hamerlynck, S. M. J. J., Doreleijers, Th. A. H., Vermeiren, R., Jansen, L. M. C., \& Cohen-Kettenis, P. T. (2007). Aggression and psychopathology in detained adolescent females. Psychiatry Research, 158, 77-85.

Hart, S. D. (1998). The role of psychopathy in assessing risk for violence: Conceptual and methodological issues. Legal and Criminological Psychology, 3, 121-137.

Hoge, R. (2002). Standardized instruments for assessing risk and need in youthful offenders. Criminal Justice and Behavior, 29, 380-396.

Hosmer, D. W., \& Lemeshow, S. (1999). Applied survival analysis. New York: Wiley.

Kruissink, M., \& Essers, A. M. M. (2001). Ontwikkeling van de jeugdcriminaliteit: periode 1980-1999. [Trends in youth criminality: period $1980-1999)$. The Hague, The Netherlands: WODC.

Lodewijks, H. P. B., Doreleijers, Th. A. H., Ruiter, C. de, \& Wit-Grouls, H. de (2003). Gestructureerde taxatie van geweldsrisico bij jongeren. (SAVRY, authorized translation into Dutch and research version). Eefde: Rentray.

Lodewijks, H. P. B., Doreleijers, Th. A. H., \& Ruiter, C. de (2008a). SAVRY risk assessment in relation to sentencing and subsequent recidivism in a Dutch sample of violent juvenile offenders. Criminal Justice and Behavior, 35, 696-709.
Lodewijks, H. P. B., Doreleijers, Th. A. H., Ruiter, C. de, \& Borum, R. (2008-b). Predictive validity of the Structured Assessment of Violence in Youth (SAVRY) during residential treatment. International Journal of Law and Psychiatry, 31, 263-271.

McCabe, K. M., Lansing, A., Garland, A., \& Hough, R. (2002). Gender differences in psychopathology, functional impairment, and familial risk factors among adjudicated delinquents. Journal of the American Academy of Child and Adolescent Psychiatry, 41, 860-867.

McEachran, A. (2001). The predictive validity of the PCL:YV and the SAVRY in a population of adolescent offenders. Unpublished Master's thesis. Burnaby, British Columbia: Simon Fraser University. Available www.fmhi.usf.edu/ mhlp/savry/SAVRY_Research.htm

McGraw, K. O., \& Wong, S. P. (1996). Forming inferences about some intraclass correlation coefficients. Psychological Methods, 1, 30-46.

McKnight, L. N., \& Loper, A. B. (2202). The effect of risk and resilience factors on the prediction of delinquency in adolescent girls. School Psychology International, 23, 186198.

Moffitt, T. E., Caspi, A., Rutter, M., \& Silva, P. A. (2001). Sex differences in antisocial behavior: Conduct disorder, delinquency, and violence in the Dunedin Longitudinal Study. Cambridge: Cambridge University Press.

Molidor, C. (1996). Female gang members: A profile of aggression and victimization. Social Work, 41, 251-256.

Moretti, M. M., DaSiva, K., \& Holland, R. (2004). Aggression and violence from an attachment perspective: Gender issues and therapeutic implications. In M. Moretti, C. Odgers, \& M. Jackson (Eds.), Girls and Aggression: Contributing factors and intervention principles (pp. 41-56). New York, NY: Kluwer Academic Press.

Moretti, M. M., Holland, R., \& McKay, S. (2001) Self-other representations and relational and overt aggression in adolescent girls and boys. Behavioral Sciences and the Law, 19, 109-126.

Mossman, D. (1994). Assessing predictions of violence: Being accurate about accuracy. Journal of Consulting and Clinical Psychology, 62, 783-792.

Odgers, C. L., \& Moretti, M. (2002). Aggressive and antisocial girls: Research update and future challenges. International Journal of Forensic Mental Health, 2, 17-33.

Odgers, C. L., Moretti, M. M., \& Reppucci, N. D. (2005). Examining the science and practice of violence risk assessment with female adolescents. Law and Human Behavior, 29, 7-27.

Odgers, C. L., Reppucci, N. D., \& Moretti, M. M. (2005). Nipping psychopathy in the bud: An examination of the convergent, predictive, and theoretical utility of the PCL:YV among adolescent girls. Behavioral Sciences and the Law, 23, 743-763.

Pajer, K. A. (1998). What happens to 'bad' girls? A review of the adult outcomes of antisocial adolescent girls. American Journal of Psychiatry, 155, 862-870.

Penney, S. R., \& Moretti, M. M. (2007). The relation of psychopathy to concurrent aggression and antisocial behavior in high-risk adolescent girls and boys. Behavioral Sciences and the Law, 25, 21-41. 
Resnick, M. D., Ireland, M., \& Borowsky, I. (2004) Youth violence perpetration: What protects? What predicts? Findings from the national longitudinal study of adolescent health. Journal of Adolescent Health, 36, 424-433.

Rice, M. E., \& Harris, G. T. (1995). Violent recidivism: Assessing predictive validity. Journal of Consulting and Clinical Psychology, 63, 737-748.

Robbins, P. C., Monahan, J., \& Silver, E. (2003). Mental disorder, violence, and gender. Law and Human Behavior, 27, 561571.

Schmidt, F., Hoge, R. D., \& Gomes, L. (2005). Reliability and validity analyses of the Youth Level of Service/Case management Inventory. Criminal Justice and Behavior, 32, $329-344$.

Serbin, L. A., Cooperman, J. M., Peters, P. L., Lehoux, P. M., Stack, D. M., \& Schwartzman, A. E. (1998). Intergenerational transfer of psychosocial risk in women with childhood histories of aggression, withdrawal, or aggression and withdrawal. Developmental Psychology, 34, 12461262.

Steffensmeier, D., Schwartz, J., Zhong, H., \& Ackerman, J. (2005). An assessment of recent trends in girls' violence using diverse longitudinal sources: Is the gender gap closing? Criminology, 43, 355-406.
Teplin, L. A., Abram, K. M., McClelland, G. M., Dulcan, M. K., \& Mericle, A. A. (2002). Psychiatric disorders in youth in juvenile detention (2002). Archives of General Psychiatry, 59, 1133-1143.

Vogel, V. de, \& Ruiter, C. de (2005). The HCR-20 in personality disordered female offenders: A comparison with a matched sample of males. Clinical Psychology \& Psychotherapy, 12, 226-240.

Vreugdenhil, C., Doreleijers, Th.A. H., Vermeiren, R., Wouters, L. F. J. M., \& Van den Brink, W. (2004). Psychiatric disorders in a representative sample of incarcerated boys in The Netherlands. Journal of the American Academy of Child and Adolescent Psychiatry, 43, 97-104.

Wartna, B. S. J., Kalidien, S. N., Tollenaar, N., \& Essers, A. A. M. (2006). Strafrechtelijke recidive van jongeren uit justitiële jeugdinrichtingen; uitstroomperiode 1997-2003. [Criminal recidivism of juveniles from juvenile justice facilities; discharge period 1997-2003). The Hague, The Netherlands: WODC.

Webster, C. D., Douglas, K. S., Eaves, D., \& Hart, S. D. (1997). HCR-20. Assessing the risk of violence. Version 2. Vancouver, BC: Simon Fraser University. 